\title{
$\mathrm{CD}^{+}$is associated with COVID-19-infected pneumonia patient recovery and recurrence
}

\section{Shuna Liu}

Affiliiated Hospital of Guangdong Medical University

\section{Wenlin Liu}

Affiliated Hospital of Guangdong Medical University

\section{Xinhua Li}

Affiliated Hospital of Guangdong Medical University

$\mathrm{Na}$ Liu

Affiliated Hospital of Guangdong Medical University

\section{Wei Deng}

Affiliated Hospital of Guangdong Medical University

\section{Chenfeng Gao}

Affiliated Hospital of Guangdong Medical University

\section{Weiqiang Zheng}

Affiliated Hospital of Guangdong Medical University

Bin Liu ( $\sim$ binliu831201@163.com )

The Affilated Hospital of Guangdong Medical University

\section{Research}

Keywords: COVID-19, CD4+, recovery, recurrence

Posted Date: June 10th, 2020

DOI: https://doi.org/10.21203/rs.3.rs-34265/v1

License: (1) (1) This work is licensed under a Creative Commons Attribution 4.0 International License. Read Full License 


\section{Abstract}

Coronavirus Disease 2019 (COVID-19)-infected pneumonia (CDIP) occurred in Wuhan, China, in December 2019, from where the disease has spread all over the world. Although the morbidity and mortality in China have been effectively controlled, the number of cases has increased rapidly in countries other than China. Here we report the epidemiological and clinical characteristics of 7 CDIP patients. We found that similar with the throat swabs, sputum induction still has a false negative rate. In addition, CD4+ count rise occurred before the disease remission, and decreased CD4+ count may be the cause of virus recurrence. These imply that CD4+ count could be a marker for recover and reinfection. Notably, we tentatively speculate that CD4+ plays a key role in the body's resistance to the COVID-19 attack on lung tissue.

\section{Background}

About December 2019, a cluster of acute viral respiratory disease, which is now known as Coronavirus Disease 2019 (COVID-19)-infected pneumonia (CDIP), appeared in Wuhan, Hubei Province, China[1, 2], from where the disease has spread all over the world[2]. As of March 14, 2020, a total of 81029 CDIP cases in China have been confirmed, and 3914 NCIP dead. Internationally, a total of 62422 CDIP cases in countries other than China have been confirmed and 2226 CDIP dead in more than 136 countries and regions. It was reported that COVID-19 could be classified in the betacoronavirus $2 b$ lineage because of its common characteristics with the coronavirus family. COVID-19 seemingly roots in bat[3], however, the exact origin of COVID-19 remains to be identified. The available evidence suggests that COVID-19 could infect human via human-to-human transmission[4]. Therefore, it is urgent to understand and identifiy the processes for prevention and control, in order to prevent contamination in the world.

\section{Methods}

\section{Study Design and Participants}

All consecutive patients with confirmed CDIP were admitted to Affiliated Hospital of Guangdong Medical University from January to February, 2020. The clinical outcomes (i.e. epidemiological and clinical characteristics) were monitored up to March, 8, 2020, the final date of follow-up.

\section{Data Collection}

The medical records of patients were analyzed by the research team of the Affiliated Hospital of Guangdong Medical University. Epidemiological, demographic, clinical, laboratory medicine, radiology, and treatment data were obtained from electronic medical records. The data were carefully reviewed by a group of highly trained doctors. Information recorded included demographic data, medical history, exposure history, background of disease, symptoms, signs, laboratory findings, computed tomographic (CT) scans, and treatment measures (i.e. antiviral therapy and immunity enhancement therapy). The 
disease onset date was deemed as the day when the symptom was detected. Symptoms, laboratory test results, CT scans, disease progression, and treatment measures during the hospital stay were collected.

\section{Results}

Epidemiological data showed that all CDIP cases have direct or indirect contact with Wuhan residents. The relationships between patients were determined. We found that Case1/Case 2 and Case3/Case 4 were couples, and COVID-19 could infect human via human-to-human transmission. The infection symptoms of CDIP suffering the background diseases were more pronounced than that of CDIP with no background diseases. The time of Case 6 onset is the same as the time of contact with Wuhan residents. At the diagnosis, CT scans data of all CDIP cases shows that the typical glass opacity lesion caused by COVID19 mainly occured in both lungs lower parts (Table1). The period between nucleic acid test (Throat swabs) became negative and lung lesion reabsorption initiation was about 6-8 day. During the follow-up after discharge, at March 5, 2020, nucleic acid test (Throat swabs) of Case5 was positive (Table2). Combining CT results with $\mathrm{CD} 4^{+}$count data, we found that $\mathrm{CD} 4^{+}$count rise occurred before the disease remission, and $\mathrm{CD} 4^{+}$count was consistent with disease progression (Table 3 and Figure1). we also found

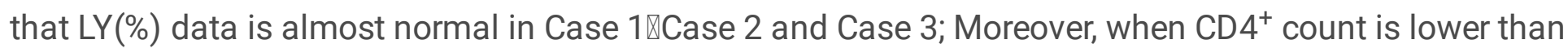
normal, LY(\%) is still almost normal in Case 1هCase 2 and Case 3(Table 3).

Table 1. The epidemiological and clinical characteristics data of 7 NCIP cases.

\begin{tabular}{|c|c|c|c|c|c|c|c|c|c|}
\hline & & & Case 1 & Case 2 & Case 3 & Case 4 & Case 5 & Case 6 & Case 7 \\
\hline Age & & & 53 & 47 & 80 & 78 & 42 & 23 & 68 \\
\hline Gender & & & male & Female & male & Female & Female & Female & Female \\
\hline Background & & & $\begin{array}{l}\text { Diabetes, } \\
\text { Favism }\end{array}$ & Diabetes & COPD & $(-)$ & $\begin{array}{l}\text { Low } \mathrm{CD}^{+} \text {, } \\
\text { High heart } \\
\text { rate }\end{array}$ & $(-)$ & Vasculitis \\
\hline \multirow[t]{2}{*}{$\begin{array}{l}\text { Wuhan } \\
\text { correlation }\end{array}$} & & $\begin{array}{l}\text { Contact with Wuhan people } \\
\text { at zhanjiang }\end{array}$ & 2020.1 .18 & $\begin{array}{c}2020.1 .18 \\
\text { indirect } \\
\text { contact }\end{array}$ & & & & 2020.1 .20 & \\
\hline & & $\begin{array}{c}\text { Return to zhanjiang from } \\
\text { Wuhan }\end{array}$ & & & 2020.1 .9 & 2020.1.9 & 2020.1 .22 & & 2020.1 .14 \\
\hline \multirow[t]{2}{*}{ Onset } & & Date & 2020.1 .29 & $(-)$ & 2020.1 .10 & $(-)$ & 2020.1 .24 & 2020.1 .20 & 2020.1 .5 \\
\hline & & Symptoms & $\begin{array}{l}\text { Fever, } \\
\text { fatigue }\end{array}$ & $(-)$ & $\begin{array}{l}\text { Fatigue, } \\
\text { chilly, } \\
\text { fever }\end{array}$ & $(-)$ & Fever & $\begin{array}{l}\text { Sore throat } \\
\text { and } \\
\text { rhinorrhea }\end{array}$ & $\begin{array}{l}\text { Poor } \\
\text { appetite, } \\
\text { fatigue }\end{array}$ \\
\hline \multirow[t]{4}{*}{ Diagnosis } & & Date & 2020.2 .1 & 2020.2 .3 & 2020.1 .20 & & 2020.1 .28 & 2020.1 .27 & 2020.1 .15 \\
\hline & & $\begin{array}{l}\text { Nucleic acid test } \\
\text { (Throat swabs) }\end{array}$ & $(+)$ & $(+)$ & $(+)$ & $(+)$ & $(+)$ & $(+)$ & $(+)$ \\
\hline & $\begin{array}{l}\mathrm{C} \\
\mathrm{T}\end{array}$ & $\begin{array}{c}\text { Glass opacity in } \\
\text { both/singe lungs lower } \\
\text { parts }\end{array}$ & $(+)$ & $(+)$ & $(+)$ & $(-)$ & $(+)$ & $(+)$ & $(+)$ \\
\hline & & Pulmonary fibrosis & $(+)$ & $2020.2 .9(+)$ & $(+)$ & $(-)$ & $2020.2 .7(+)$ & $(-)$ & $(+)$ \\
\hline
\end{tabular}


Table 2. The process of 7 NCIP cases.

\begin{tabular}{|c|c|c|c|c|c|c|c|c|}
\hline & & Case 1 & Case 2 & Case 3 & Case 4 & Case 5 & Case 6 & Case 7 \\
\hline \multirow[t]{5}{*}{ Process } & Deterioration & $(-)$ & $(+)$ & $(-)$ & $(-)$ & $2020.2 .7(+)$ & $(-)$ & $(-)$ \\
\hline & $\begin{array}{l}\text { Nucleic acid } \\
\text { test } \\
\text { (Throat swabs) }\end{array}$ & $\begin{array}{c}2020.2 .13(-) \\
2020.3 .4(-)\end{array}$ & 2020.2.14 (-) & $2020.1 .20(+)$ & $\begin{array}{c}2020.1 .20(+) \\
2020.1 .22(-) \\
2020.1 .24(+) \\
2020.1 .30(-) \\
2020.2 .1(-)\end{array}$ & $\begin{array}{l}2020.2 .10(-) \\
2020.2 .21(-) \\
2020.2 .24(-) \\
2020.2 .26(-)\end{array}$ & $2020.2 .2(-)$ & \\
\hline & $\begin{array}{l}\text { Nucleic acid } \\
\text { test (induced } \\
\text { sputum) }\end{array}$ & $\begin{array}{c}2020.2 .13(+) \\
2020.3 .4(-)\end{array}$ & & $\begin{array}{c}2020.1 .30(-) \\
2020.2 .1(-)\end{array}$ & & $\begin{array}{l}2020.2 .10(+) \\
2020.2 .21(+) \\
2020.2 .24(-) \\
2020.2 .26(-)\end{array}$ & & $\begin{array}{l}2020.1 .21(-) \\
2020.1 .23(-) \\
2020.1 .25(-)\end{array}$ \\
\hline & $\begin{array}{l}\text { Out of the } \\
\text { hospital }\end{array}$ & 2020.3 .5 & 2020.2 .27 & 2020.2 .5 & 2020.1 .23 & $2020 / 2 / 27$ & 2020.2 .10 & 2020.1 .29 \\
\hline & Recurrence & $(-)$ & $(-)$ & $(-)$ & $(-)$ & $2020.3 .5(+)$ & $(-)$ & $(-)$ \\
\hline
\end{tabular}

Table3. Blood CD4 ${ }^{+}$count and LY (\%) of 6 NCIP cases

\begin{tabular}{|c|c|c|c|c|c|c|c|c|c|c|c|}
\hline \multicolumn{2}{|c|}{ Case 1} & \multicolumn{2}{|c|}{ Case 2} & \multicolumn{2}{|c|}{ Case 4} & \multicolumn{2}{|c|}{ Case 5} & \multicolumn{2}{|c|}{ Case 6} & \multicolumn{2}{|c|}{ Case 7} \\
\hline $\mathrm{CD}^{+}$ & LY (\%) & $\mathrm{CD}^{+}$ & LY (\%) & $\mathrm{CD}^{+}$ & LY (\%) & $\mathrm{CD}^{+}$ & LY (\%) & $\mathrm{CD}^{+}$ & LY (\%) & $\mathrm{CD}^{+}$ & LY (\%) \\
\hline $\begin{array}{c}380 \\
(2.2)\end{array}$ & $\begin{array}{l}30.2 \\
(2.2)\end{array}$ & $\begin{array}{c}546 \\
(2.5)\end{array}$ & $\begin{array}{l}18.9 \\
(2.5)\end{array}$ & $\begin{array}{c}878 \\
(2.5)\end{array}$ & $\begin{array}{l}26.5 \\
(2.5)\end{array}$ & $\begin{array}{c}298 \\
(1.28)\end{array}$ & $\begin{array}{c}28.2 \\
(1.28)\end{array}$ & $\begin{array}{l}1009 \\
(2.8)\end{array}$ & $\begin{array}{c}31 \\
(2.8)\end{array}$ & $\begin{array}{c}285 \\
(1.16)\end{array}$ & $\begin{array}{c}15 \\
(1.16)\end{array}$ \\
\hline $\begin{array}{c}629 \\
(2.11)\end{array}$ & $\begin{array}{c}25.9 \\
(2.11)\end{array}$ & $\begin{array}{c}250 \\
(2.10)\end{array}$ & $\begin{array}{l}20.93 \\
(2.10)\end{array}$ & & & $\begin{array}{c}320 \\
(2.12)\end{array}$ & $\begin{array}{c}21.1 \\
(2.12)\end{array}$ & & & $\begin{array}{c}439 \\
(1.23)\end{array}$ & $\begin{array}{l}23.34 \\
(1.23)\end{array}$ \\
\hline $\begin{array}{c}592 \\
(2.18)\end{array}$ & $\begin{array}{c}24.9 \\
(2.18)\end{array}$ & $\begin{array}{c}439 \\
(2.12)\end{array}$ & $\begin{array}{c}22.2 \\
(2.12)\end{array}$ & & & $\begin{array}{c}181 \\
(2.26)\end{array}$ & $\begin{array}{c}6.2 \\
(2.26)\end{array}$ & & & & \\
\hline $\begin{array}{c}525 \\
(2.24)\end{array}$ & $\begin{array}{c}30 \\
(2.24)\end{array}$ & $\begin{array}{c}756 \\
(2.17)\end{array}$ & $\begin{array}{c}30.4 \\
(2.17)\end{array}$ & & & & & & & & \\
\hline $\begin{array}{c}589 \\
(2.28)\end{array}$ & $\begin{array}{l}29.59 \\
(2.28)\end{array}$ & & & & & & & & & & \\
\hline
\end{tabular}

\section{Discussion}

Case1/Case2 and Case3/Case3 are couples, which is consistent with the report that a familial cluster of pneumonia associated with the COVID-19 showed person-to-person transmission[4]. Moreover, we found that the period between negative nucleic acid test (Throat swabs) and lung lesion reabsorption initiation is about 6-8 day. In addition to age, disease progression may also be related to the body's health. The infection symptoms of CDIP suffering the background diseases are more pronounced than that of CDIP with no background diseases, which is likely to affect the CDIP patient survival. The time of Case 6 onset is the same as the time of contact with Wuhan residents, although this patient is young and has no background disease. Epidemiological data showed that compared with others, Case 6 contacted and dined with a large number of Wuhan residents in Zhanjiang at on one day. Hence, exposure to large amounts of the virus may be the inducer of onset acceleration. 
According to our previous results[5], in order to improve the positive rate of diagnosis and make a basic guarantee for the improvement of defense and prevention and control, the method of inducing sputum could be used to detect nucleic acid for high-risk population exposed to epidemic area. It was found during follow-up that Case 5, as Case 2 was reported at Lancet Infect Dis March 12, 2020 nucleic acid test (Throat swabs) is positive at March 5, 2020 but has no symptoms, however, the paper shows both nucleic acid test (induced sputum) and nucleic acid test (Throat swabs) of Case 2 were negative. There may be 3 reasons that could result in the CDIP reinfection: After a series of treatments, the proliferation of COVID-19 is effectively controlled, showing low load or dormant, even lurking in other organs, such as the intestinal, circulatory systems and urinary system[6-8], finally, the virus persists in the body but has no symptoms same with HBV and HIV; $\mathbb{X S i m i l a r}$ with the throat swabs, sputum induction still has a false negative rate. CT scans show that glass opacity lesion mainly located in lungs lower parts, as far as possible, sputum in the base of the lungs should be collected for identification; $\mathbb{N N o t}$ only $\mathrm{CD} 4^{+}$count of Case 2 is lower than that of other cases, but also lower than normal level.

We found that CD 4 count is consistent with disease progression: in case 1 and Case $7, C D 4^{+}$count rised from 380 and 285 to the normal, respectively; as deterioration occured in Case $2, \mathrm{CD}^{+}$count was decreased from 546 to 250 ; when Case 5 was discharged from the hospital, the $\mathrm{CD} 4^{+}$count was below normal. We also found that LY(\%) data is almost normal in Case 1囚Case 2 and Case 3; Moreover, when $\mathrm{CD}^{+}$count is lower than normal, $\mathrm{LY}(\%)$ is still almost normal in Case $1 \mathbb{}$ Case 2 and Case 3. However, previous studies have shown that peripheral lymphocytes decrease is one significant marker of CDIP diagnosis[9]. Above all, CD $4^{+}$may be more sensitive to COVID-19 infections than that of LY(\%).It was reported that $C D 4^{+}$is mainly expressed in T cells[10], and its count influences immunological recovery of HIV infection[11], HIV therapeutic methods may be used to treat the COVID-19 infection. We further compared the change time of $\mathrm{CT}$ scan and $\mathrm{CD} 4^{+}$count, and found that $\mathrm{CD} 4^{+}$count rise occurred before the disease remission, which means that $\mathrm{CD} 4^{+}$count rise may be a marker for recover, Therefore, when $\mathrm{CD} 4^{+}$count is lower than normal, it may be the cause of virus recurrence, which may be confirmed in Case 5. CDIP patients should be treated with immune-enhancing drugs such asy-globulin and Thymosin used in Case 1 and Case5 treatment.

\section{Conclusions}

The epidemiological, clinical characteristics and treatment of CDIP were summarized and analyzed. CD4 ${ }^{+}$ count may be a marker for recover and reinfection. We preliminarily could speculate that CD4+ plays a key role in the body's resistance to the COVID-19 attack on lung tissue and boosting immunity is useful to clear the COVID-19 and reduce the risk of infection. More patient data are needed for statistical analysis to verify this conclusion.

\section{Abbreviations}

CPIDICoronavirus Disease 2019 (COVID-19)-infected pneumonia 


\section{Declarations}

Availability of Data and Materials: The data used and/or analyzed in the study are available from the corresponding author on reasonable request.

Ethics Approval and Consent to Participate: The study protocol, any amendments, the informed consent, and other information that required pre-approval were reviewed and approved by a national, regional, or investigational site ethics committee or institutional review board (IRB), in accordance with the International Council for Harmonisation of Technical Requirements for Registration of Pharmaceuticals for Human Use Good Clinical Practice and applicable country-specific requirements. All study patients provided written informed consent.

Consent for Publication: Not applicable.

Author Contributions: Shuna Liu, Wenlin Liu and Xinhua Li had full access to all of the data in the study; Bin Liu and Chenfeng Gao wrote the manuscript; Bin Liu and Weiqiang Zheng take responsibility for the integrity of the data and the accuracy of the data analysis; Deli Shi revised English writing of the manuscript.

Competing interests: None reported.

Funding/Support This work was supported by the Doctoral research start-up fund, Affiliated Hospital of Guangdong Medical University (grant no.20303Z20190002).

\section{Acknowledgments}

We would like to thank Professor Mingyi Li, who provides the guidance in writing an article $\varangle$ We also need to thank the colleagues of Infectious Diseases Center, ICU, Traditional Chinese Medicine Department, and Radiology department.

\section{References}

1. Lu H, Stratton CW, Tang YW: Outbreak of pneumonia of unknown etiology in Wuhan, China: The mystery and the miracle. Journal of medical virology 2020, 92(4):401-402.

2. Hui DS, E IA, Madani TA, Ntoumi F, Kock R, Dar O, Ippolito G, McHugh TD, Memish ZA, Drosten C et al: The continuing 2019-nCoV epidemic threat of novel coronaviruses to global health - The latest 2019 novel coronavirus outbreak in Wuhan, China. International journal of infectious diseases : IJID : official publication of the International Society for Infectious Diseases 2020, 91:264-266.

3. Chen N, Zhou M, Dong X, Qu J, Gong F, Han Y, Qiu Y, Wang J, Liu Y, Wei Y et al: Epidemiological and clinical characteristics of 99 cases of 2019 novel coronavirus pneumonia in Wuhan, China: a 
descriptive study. Lancet (London, England) 2020, 395(10223):507-513.

4. Chan JF, Yuan S, Kok KH, To KK, Chu H, Yang J, Xing F, Liu J, Yip CC, Poon RW et al: A familial cluster of pneumonia associated with the 2019 novel coronavirus indicating person-to-person transmission: a study of a family cluster. Lancet (London, England) 2020, 395(10223):514-523.

5. Huanqin Han QL, Fan Mo, Lieming Long, Weiqiang Zheng: SARS-CoV-2 RNA more readily detected in induced sputum than in throat swabs of convalescent COVID-19 patients. Lancet Infect Dis 2020, S1473-3099(20)30174-2.

6. Young BE, Ong SWX, Kalimuddin S, Low JG, Tan SY, Loh J, Ng OT, Marimuthu K, Ang LW, Mak TM et al: Epidemiologic Features and Clinical Course of Patients Infected With SARS-CoV-2 in Singapore. Jama 2020.

7. Xie C, Jiang L, Huang G, Pu H, Gong B, Lin H, Ma S, Chen X, Long B, Si G et al: Comparison of different samples for 2019 novel coronavirus detection by nucleic acid amplification tests. International journal of infectious diseases : IJID : official publication of the International Society for Infectious Diseases 2020.

8. Ling Y, Xu SB, Lin YX, Tian D, Zhu ZQ, Dai FH, Wu F, Song ZG, Huang W, Chen J et al: Persistence and clearance of viral RNA in 2019 novel coronavirus disease rehabilitation patients. Chinese medical journal 2020.

9. Qin C, Zhou L, Hu Z, Zhang S, Yang S, Tao Y, Xie C, Ma K, Shang K, Wang W et al: Dysregulation of immune response in patients with COVID-19 in Wuhan, China. Clinical infectious diseases : an official publication of the Infectious Diseases Society of America 2020.

10. Brummelman J, Pilipow K, Lugli E: The Single-Cell Phenotypic Identity of Human CD8(+) and CD4(+) T Cells. International review of cell and molecular biology 2018, 341:63-124.

11. Carvalho-Silva WHV, Andrade-Santos JL, Dos Santos Guedes MC, Crovella S, Guimaraes RL: CCR5 genotype and pre-treatment CD4+ T-cell count influence immunological recovery of HIV-positive patients during antiretroviral therapy. Gene 2020:144568.

\section{Figures}




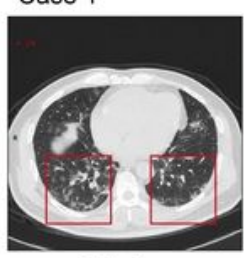

Feb.1

Case 2

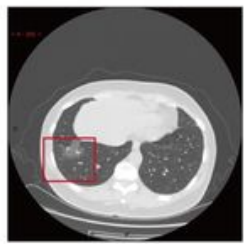

Feb.4

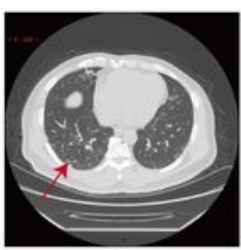

Feb.13

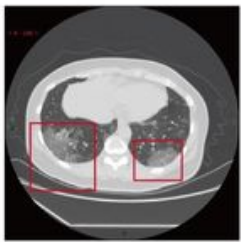

Feb.9

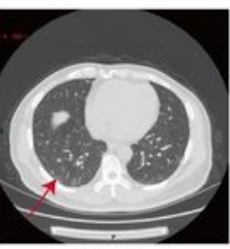

Feb.20

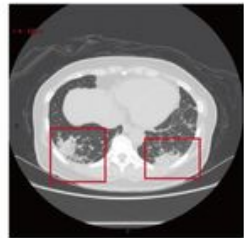

Feb.16

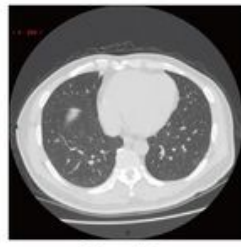

March.1

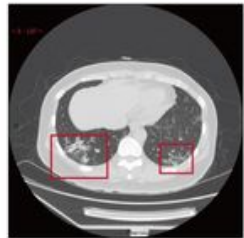

Feb.24

Case 4
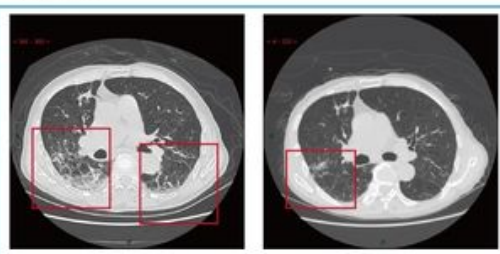

Feb.2

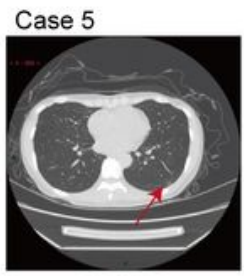

Jan.25

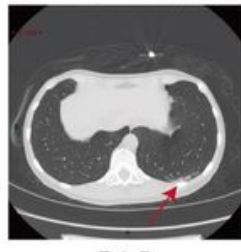

Feb.7

Case 6

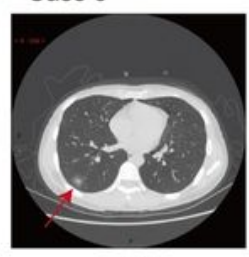

Jan. 27

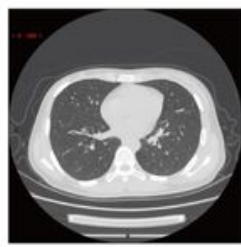

Feb. 8

Case 7

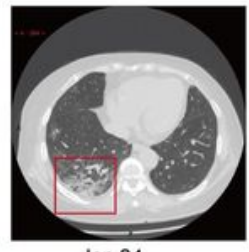

Jan.24

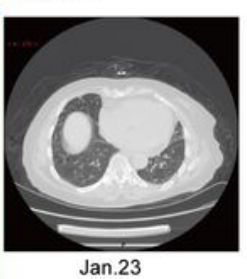

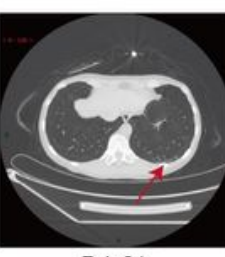

Feb.24

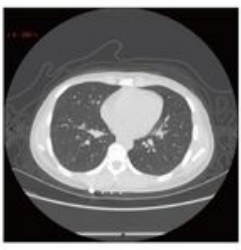

Feb.16

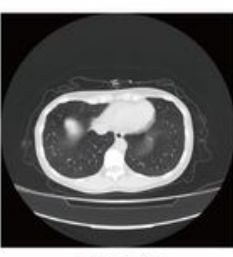

March.13

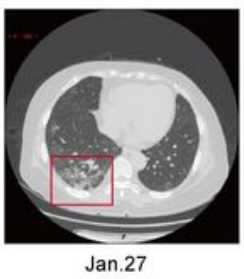

Figure 1

Lung CT scans of case 1-7 